\title{
Recent patent applications in DNA synthesis
}

\begin{tabular}{ll} 
Patent \# & Subject \\
\hline JP 2006337153 & $\begin{array}{l}\text { A DNA determination system comprising a DNA chip } \\
\text { apparatus for fixing DNA, a nucleic acid tank apparatus } \\
\text { for storing nucleic acids for synthesizing DNA, a DNA } \\
\text { synthesis determination apparatus for determining DNA } \\
\text { of biological material and a DNA information-providing } \\
\text { apparatus for providing the information on the DNA. }\end{array}$ \\
& $\begin{array}{l}\text { A DNA synthetic inhibition material with respect to } \\
\text { tumor cells, comprising Phellinus linteus mycelium } \\
\text { JP 2006249007 }\end{array}$ \\
& $\begin{array}{l}\text { sulture as an active ingredient, which is prepared by } \\
\text { A method of performing a DNA polymerase reaction at } \\
\text { improved efficiency involving the use of a pyridinium } \\
\text { compound in a reaction mixture containing a DNA } \\
\text { W0 2006059075 }\end{array}$ \\
\hline $\begin{array}{l}\text { polymerase; useful in the enzymatic synthesis of nucleic } \\
\text { acids using primer extension and DNA sequencing. }\end{array}$
\end{tabular}

Assignee(s)
Toppan Printing Co.
(Tokyo)

\section{Priority}

Kobayashi C, Kobayashi F 3/11/2005 9/21/2006

Tsurumi M application date Publication date

$\begin{array}{ccc}\text { Bioline (London) } \quad \begin{array}{r}\text { Ignatov K, } \\ \text { Kramarov V }\end{array} & 11 / 30 / 2004 \quad 6 / 2006 \\ 6 / 2006\end{array}$

\begin{abstract}
US 20060100215
New 8a,9-dihydro-4a-H-isothiazolo[5,4-b]-quinoline-3,
\end{abstract} WO 2006118605 4-dione compounds; useful as bacterial DNA synthesis inhibitors to treat or prevent bacterial or protozoal infection.

Song $Y$, Wang $Q$,

(New Haven, CT,

KR 2006030835 A DNA sequencing method, using a DNA synthesis reaction provided to remove the electrophoresis step in DNA sequencing, that increases the length of the nucleotide sequence to be sequenced and improves the speed and accuracy of the DNA sequencing.

WO 2005111209 JP 2005328709, EP 1752534

\section{WO 2006026611}

\section{US 20060008833}

WO 2006006079 EP 1734985 , AU 2005261363
A method for performing high-speed PCR useful for gene expression analysis, involving carrying out PCR under a specific temperature change, using a heat-resistant Thermococcus kodakaraensis DNA polymerase exhibiting higher speed for DNA synthesis.

\section{A new nucleic acid molecule comprising recognition} signals for reverse transcriptase-mediated RNA and DNA synthesis and processing; useful for regulating, altering or reprogramming gene expression.

A method of synthesizing error-corrected DNA constructs by assembling synthesized oligonucleotides having errors into a longer construct, testing for errors and using the test information to synthesize repair oligonucleotides for repairing errors in the construct.

A method for inhibiting DNA synthesis, p44/p42 mitogen-activated protein (MAP) kinase activation or tube formation in arterial endothelial cells, comprising contacting the arterial endothelial cells with an ephrinB2.
Bradbury BJ, Deshpande M, Hashimoto A,

Lucien E,

Pucci MJ,

Wiles JA,

Achillion

Pharmaceuticals

USA)

\section{Bradbury BJ,}

Deshpande M,

Hashimoto A,

Lucien E,

Pucci MJ,

Song $Y$, Wang $Q$,

Wiles JA

Chun HS

Chun HS

10/6/2004

4/11/2006

\begin{tabular}{|c|c|c|c|}
\hline $\begin{array}{l}\text { Toyo Boseki } \\
\text { (Osaka, Japan), } \\
\text { Toyobo (Osaka, } \\
\text { Japan) }\end{array}$ & $\begin{array}{l}\text { Nakajima T, } \\
\text { Oka M, } \\
\text { Segawa M }\end{array}$ & $5 / 18 / 2004$ & $\begin{array}{l}\text { 11/24/2005, } \\
\text { 12/2/2005, } \\
\text { 2/14/2007 }\end{array}$ \\
\hline Mitchell LG & Mitchell LG & $8 / 31 / 2004$ & 8/30/2005 \\
\hline Jacobson JM & Jacobson JM & $7 / 12 / 2004$ & $7 / 8 / 2005$ \\
\hline $\begin{array}{l}\text { Aqumen } \\
\text { Biopharmaceuticals } \\
\text { (Fukuoka, Japan) }\end{array}$ & $\begin{array}{l}\text { Fujisawa K, } \\
\text { Hata Y, } \\
\text { Ishibashi T, } \\
\text { Kagimoto T }\end{array}$ & 4/5/2004 & $4 / 5 / 2005$ \\
\hline
\end{tabular}

Source: Thomson Scientific Search Service. The status of each application is slightly different from country to country. For further details, contact Thomson Scientific, 1800 Diagonal Road, Suite 250, Alexandria, Virginia 22314, USA. Tel: 1 (800) 337-9368 (http://www.thomson.com/scientific). 